University of Rhode Island

DigitalCommons@URI

The Rhode Island Current Conditions Index

Economics

7-2006

\title{
Rhode Island Current Conditions Index - July 2006
}

Leonard Lardaro

University of Rhode Island, lardaro@uri.edu

Follow this and additional works at: https://digitalcommons.uri.edu/ricci

Part of the Econometrics Commons

Terms of Use

All rights reserved under copyright.

\section{Recommended Citation}

Lardaro, Leonard, "Rhode Island Current Conditions Index -- July 2006" (2006). The Rhode Island Current Conditions Index. Paper 76.

https://digitalcommons.uri.edu/ricci/76

This Article is brought to you for free and open access by the Economics at DigitalCommons@URI. It has been accepted for inclusion in The Rhode Island Current Conditions Index by an authorized administrator of DigitalCommons@URI. For more information, please contact digitalcommons@etal.uri.edu. 


\section{GURRENT}

BONDITIONS

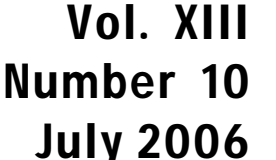

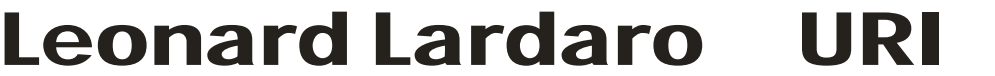

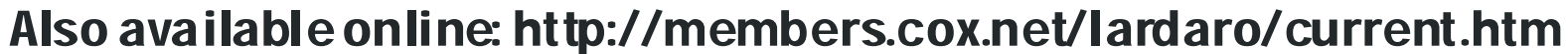

For the last four months, the performance of Rhode Island's economy can best be summarized as one step forward, one step back. In April, the Current Conditions Index was 58. For May, it fell below its neutral value (of 50) to 42 . It then increased back to 58 in June, only to fall back to 50 in July. Only six of the twelve $\mathrm{CCl}$ indicators improved in July, our first reading for the this quarter. And, for the second consecutive month, the $\mathrm{CCl}$ has fallen behind its value one year earlier.

There were a few impressive indicator performances in July. Retail Sales had a healthy rate of increase, layoffs declined significantly, Employment Service J obs rose for the fourth consecutive month, and Manufacturing Wage growth sustained a pace above 2 percent.

Retail Sales grew by 4.4 percent in July compared to one year ago, its most rapid rate of growth since March. Some of this was related to back-to-school shopping. What made this performance impressive is the fact that US Consumer Sentiment fell at a double-digit rate $(-12.5 \%)$ in July.

But, like the US economy, the pace of economic activity in Rhode Island remains sluggish. In July, new home construction, as measured by Single-Unit Permits, fell by a whopping 29.1 percent compared to a year ago. July was the fourth consecutive month with a rate of decline in excess of 20

\section{Indicators - \% Change}

Government Employment $\quad-0.2$

US Consumer Sentiment $\quad-12.5$

Single-Unit Permits $\quad-29.1$

Retail Sales

Employment Services J obs

Priv. Serv-Prod Employment

Total Manufacturing Hours

Manufacturing Wage

Labor Force

Benefit Exhaustions

New Claims

Unemployment Rate

$\mathbf{Y}=$ I mproved Value

percent. Manufacturing performance remained mixed. Total Manufacturing Hours fell by 3 percent, its fourth consecutive decline in excess of 2.5 percent. But the Manufacturing Wage rose by 2.2 percent, a healthy pace that has been sustained since January of this year.

The most significant dichotomy in our economic performance

occurred in the labor market. Layoffs, as measured by New Claims for Unemployment Insurance fell by a strong 18.8 percent. While this was occurring, Benefit Exhaustions, which reflects long-term unemployment, rose sharply, by 25.7 percent in July. How can layoffs be declining while long-term unemployment is rising? The answer is job growth. And that has been very disappointing of late.

Employment Service Jobs, which includes the demand for "temps," grew by only 1.0 percent in July, a clear moderation from the past three months. Along with this, Private ServiceProducing Employment growth remained below a onepercent rate $(+0.5 \%)$ in July, its weakest performance in well over a year. And Government Employment fell slightly in July, by 0.2 percent. In light of sluggish job growth, the number of continuing Unemployment Insurance Claims rose by over 15 percent compared to last July.

Finally, while Labor Force growth remained fairly strong, rising by 1.8 percent once again in July, our Unemployment Rate jumped all the way from 5.0 percent last July to 5.6 percent this July. It has remained well above the national rate and far from the level consistent with full employment here (of $4.2 \%$ ) for some time now.

\section{$\mathrm{CCl}$ Over the Past 13 Months}

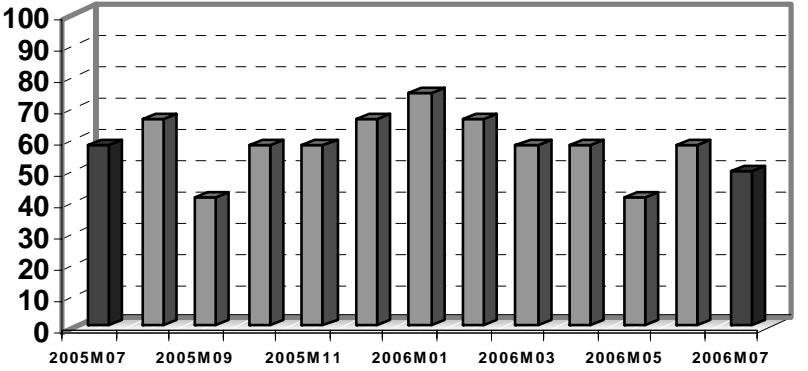

THE BOTTOM LINE

Like the nation, the fairly strong pace of economic activity here in the first quarter has given way to slower activity ever since. For Rhode I sland, several areas are performing well. Unfortunately, these bright spots continue to be offset by weaknesses in other areas, making it appear that our economy is weaker than it really is.

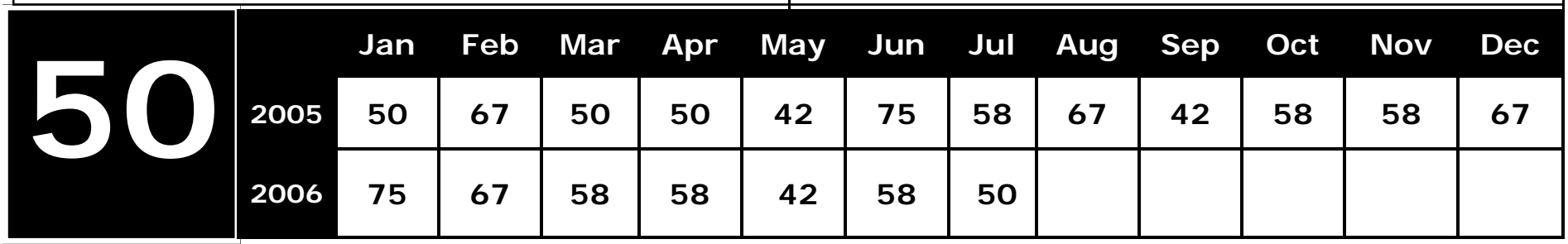

